\title{
Structure of a 4:1:4 supramolecular assembly of neutral TiiiiPO cavitands and tetra-(N-methylpyridinium)- porphyrin iodide
}

\author{
Rita De Zorzi, ${ }^{\dagger}$ Béatrice Dubessy, ${ }^{\ddagger}$ Jean-Christophe Mulatier, ${ }^{\ddagger}$ Silvano Geremia ${ }^{\dagger}{ }^{\text {Lucio }}$ \\ Randaccio $^{*, \dagger}$ and Jean-Pierre Dutasta ${ }^{*,+}$
}

\section{Supporting Information}

List of Content

Experimental Section
Page

$\mathrm{S} 2-\mathrm{S} 3$

Figure S1. Thermal Ellipsoid plot of the crystallographic structure. of $\left[\mathrm{TMPyP}^{4+}\right]\left[4 \mathrm{I}^{-}\right] \cdot \mathbf{1}_{4}$.

Figure S2. ${ }^{1} \mathrm{H}$ NMR spectrum $(200 \mathrm{MHz}, \mathrm{DMSO})$ of $\left[\mathrm{TMPyP}^{4+}\right]\left[4 \mathrm{I}^{-}\right]$.

Figure S3. ${ }^{1} \mathrm{H}$ NMR spectrum $\left(500 \mathrm{MHz}, \mathrm{CDCl}_{3}\right)$ of cavitand $\mathbf{1}$.

Figure S4. ${ }^{1} \mathrm{H}$ NMR spectrum $\left(500 \mathrm{MHz}, \mathrm{CDCl}_{3}\right)$ of complex $\left[\mathrm{TMPyP}^{4+}\right]\left[4 \mathrm{I}^{-}\right] \cdot \mathbf{1}_{4} . \quad \mathrm{S} 5$

Table S1. Anion Effect on the Chemical Shifts $\delta(\mathrm{ppm})$ of $H(1), H(2)$ and $\mathrm{CH}_{2} \mathrm{CH}_{2}$ Protons of 1 in Guest@1 Complexes 
General. ${ }^{1} \mathrm{H}-\mathrm{NMR}$ spectra were recorded with Bruker DPX $200\left({ }^{1} \mathrm{H} 200.13 \mathrm{MHz}\right)$ and Varian Unity $500\left({ }^{1} \mathrm{H} 499 \mathrm{MHz}\right)$ spectrometers. Chemical shifts are given relative to the residual solvent $\left[d\left(\mathrm{CHCl}_{3}\right)=7.24 \mathrm{ppm}\right]$. Posphorylated cavitand $\mathbf{1},{ }^{1}$ and tetra-(N-methylpyridinium)porphyrin iodide $\left[\mathrm{TMPyP}^{4}\right]\left[4 \mathrm{I}^{-}\right]$were prepared according to the published procedures. ${ }^{2}$

Preparation of $\left[\mathbf{T M P y P}^{4+}\right]\left[\mathbf{4 I}^{-}\right] \cdot \mathbf{1}_{\mathbf{4}}$. Typically, cavitand $\mathbf{1}\left(71.6 \mathrm{mg}, 41.210^{-3} \mathrm{mmol}\right)$ and $\mathrm{TMPyP}^{4+} \cdot 4 \mathrm{I}^{-}$guest $\left(15.2 \mathrm{mg}, 12.810^{-3} \mathrm{mmol}\right)$ were dissolved in $\mathrm{CHCl}_{3}$. $\mathrm{n}$-Hexane was then slowly added until the solution starts to be cloudy. Crystals of $\left[\mathrm{TMPyP}^{4+}\right]\left[4 \mathrm{I}^{-}\right] \cdot \mathbf{1}_{4}$ precipitated from the mixture and were recovered by filtration.

\section{Solid-state structure analysis}

Orange-brown platelet-shaped crystals of the complex suitable for X-ray analysis were grown by adding $\mathrm{n}$-hexane to a solution obtained by dissolving the cavitand and the porphyrin (4:1 ratio) in a minimum amount of chloroform. Data collection was performed at the X-ray diffraction beamline of Elettra Synchrotron, Trieste (Italy) (monochromatic wavelength $\lambda=0.9 \AA$ ) using a Mar CCD detector with the rotating crystal method. The crystal soaked with Paratone as cryoprotectant, was mounted in a loop and flash frozen to $100 \mathrm{~K}$. The diffraction data were indexed and integrated using DENZO and scaled with SCALEPACK. ${ }^{3}$ The structure was solved in the acentric $P c a 2_{1}$ space group by direct methods using SHELXS ${ }^{4}$ and Fourier analyses and refined by the full-matrix least-squares based on $F^{2}$ using SHELXL-97. ${ }^{5}$ Attempts to solve the structure in the centrosymmetric $\mathrm{Pbcm}$ space group failed.

The electron density maps and the refinement of the structure showed that there is one crystallographic independent supramolecular complex, formed by four phosphonato resorcinarene molecules arranged around one positive charged porphyrin and four iodide ions. The highest electron density peaks, after I and $\mathrm{P}$ atoms, corresponded to the $\mathrm{Cl}$ atoms of chloroform molecules with full occupancy. The analysis of the electron density maps revealed the presence of 20 chloroform molecules in the asymmetric unit, six of which with full occupancy and fourteen disordered over thirty sites with partial occupancy. Four phenyl groups present on the lower rim of three resorcinarene molecules are disordered over two sites. Due to the low data-to-parameter ratio, geometrical restrains for pyridyl groups of the porphyrin molecule, for aromatic groups on the upper rim and the lower rim of resorcinarene molecules and for chloroform molecules have been introduced in the model. Restrains have also been introduced for the anisotropic thermal parameters, using the cards SIMU (atoms 
closer than $1.7 \AA$ were restrained to have the same Uij components) and ISOR (Uij components were restrained to approximate the isotropic behavior). During the refinement, the hydrogen atoms of the methyl groups of porphyrin molecule were included at fixed distance from carbon atom to which they were bonded, with the torsion angles allowed to refine. The remaining hydrogen atoms of porphyrin molecule and the hydrogen atoms of resorcinarene molecules were included at calculated positions with isotropic $U$ factors equal to $1.2 \mathrm{Ueq}$ of the carbon atom to which they are bonded, using a riding model that introduces no extra parameters. In the final refinement, all non-hydrogen non-disordered atoms and all $\mathrm{Cl}$ atoms with occupancy factors higher than 0.4 were treated anisotropically. In order to further investigate the solvent-containing cavities, the SQUEEZE function of the program PLATON was used. ${ }^{6}$ A residual electron density of 815 electrons/cell was found in these remaining voids ( $10 \%$ of cell volume). The remaining electron density corresponds to about three molecules of chloroform in the asymmetric unit. A refinement using reflections modified by the SQUEEZE procedure behaved well and the R-factor was reduced from 0.172 to 0.134 . The relatively large values of $R_{1}$ and $w R_{2}$ are common for supramolecular complexes having very large unit cells and huge amount of disordered solvent molecules. ${ }^{7}$ The electron count per cell was not included in the calculated density and in $F(000)$. Essential crystal data and refinement details are reported in Table 3.

\section{References}

(1) Delangle, P.; Mulatier, J.-C.; Tinant, B.; Declercq, J.-P.; Dutasta, J.-P. Eur. J. Org. Chem. 2001, 3695-3704.

(2) Casas, C.; Saint-Jalmes, B.; Loup, C.; Lacey, C.J.; Meunier, B. J. Org. Chem. 1993, 58, 2913-2917.

(3) Otwinowski, Z.; Minor, W. Methods in Enzymology 1997, 276, 307-326.

(4) Sheldrick, G. M. Acta Cryst. A 1990, 46, 467-473.

(5) Sheldrick, G. M. SHELXL-97 1997, University of G_ttingen.

(6) Spek, A.L. Acta Cryst. A, 1990, 46, C-34.

(7) Cotton, F. A.; Lin, C.; Murillo, C. A. Inorg. Chem. 2001, 40, 575-577. 


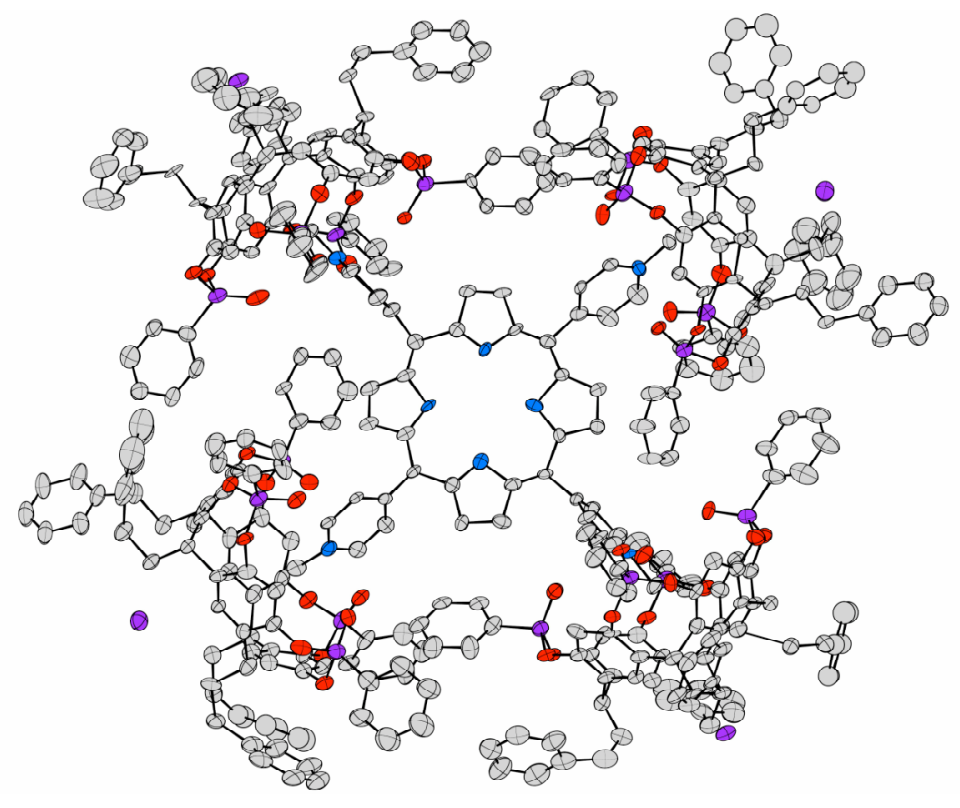

Figure S1. Thermal Ellipsoid plot of the crystallographic structure. The probability level is set to $20 \%$. The solvent (chloroform) molecules and the disorder fragments have been omitted for clarity.

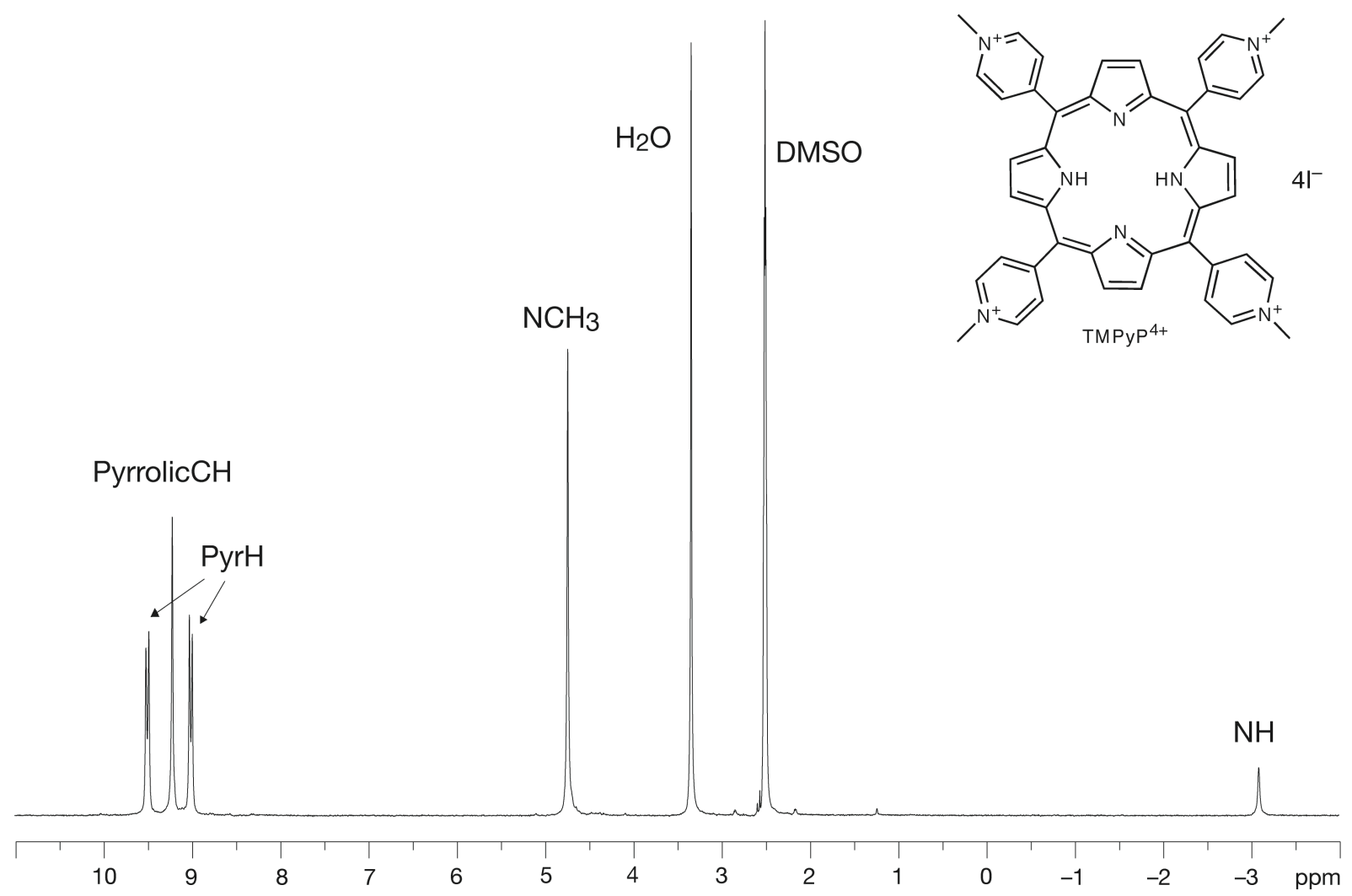

Figure S2. ${ }^{1} \mathrm{H}$ NMR spectrum $(200 \mathrm{MHz}, \mathrm{DMSO})$ of $\left[\mathrm{TMPyP}^{4+}\right]\left[4 \mathrm{I}^{-}\right]$. 


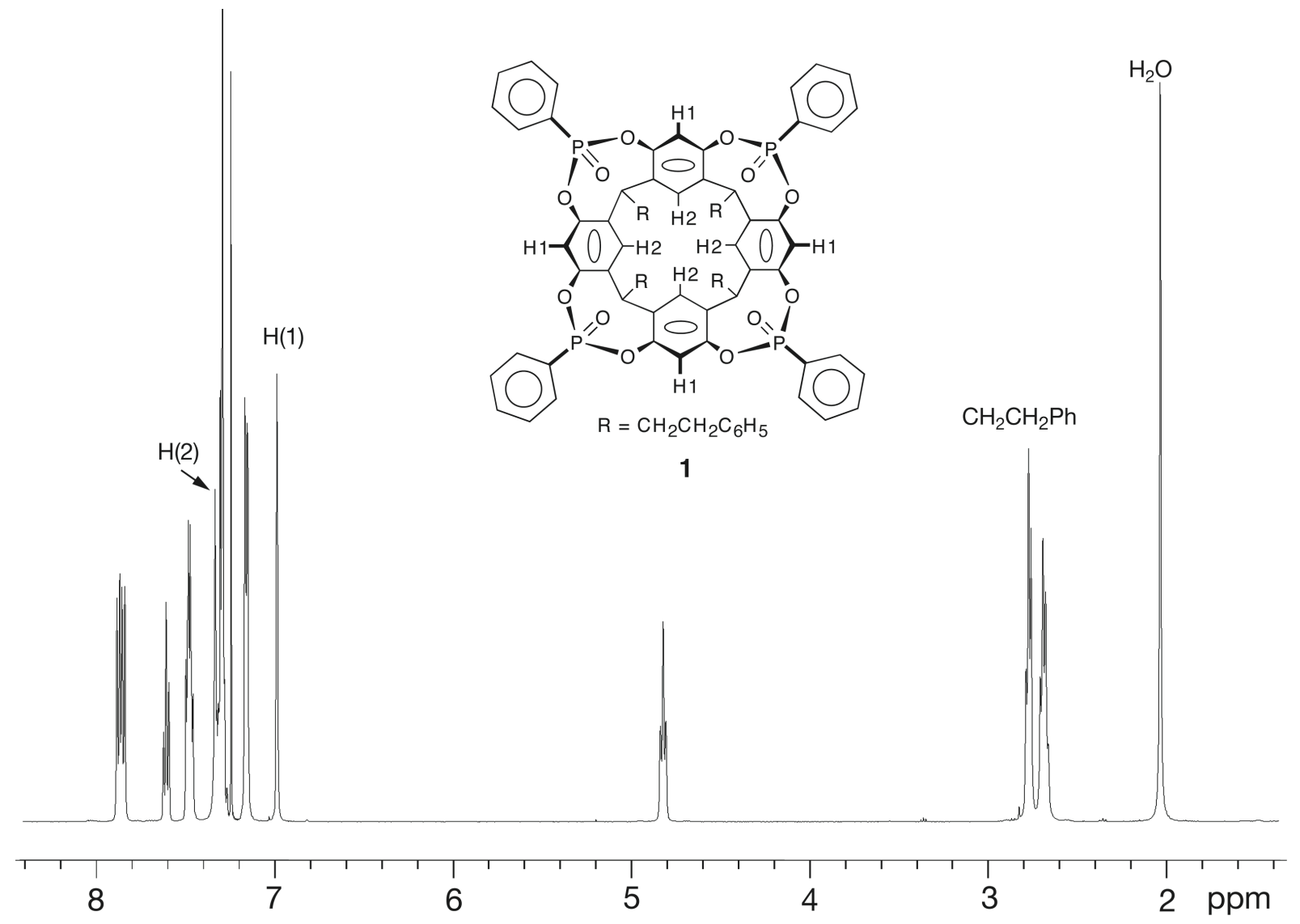

Figure S3. ${ }^{1} \mathrm{H}$ NMR spectrum $\left(500 \mathrm{MHz}, \mathrm{CDCl}_{3}\right)$ of cavitand $\mathbf{1}$.

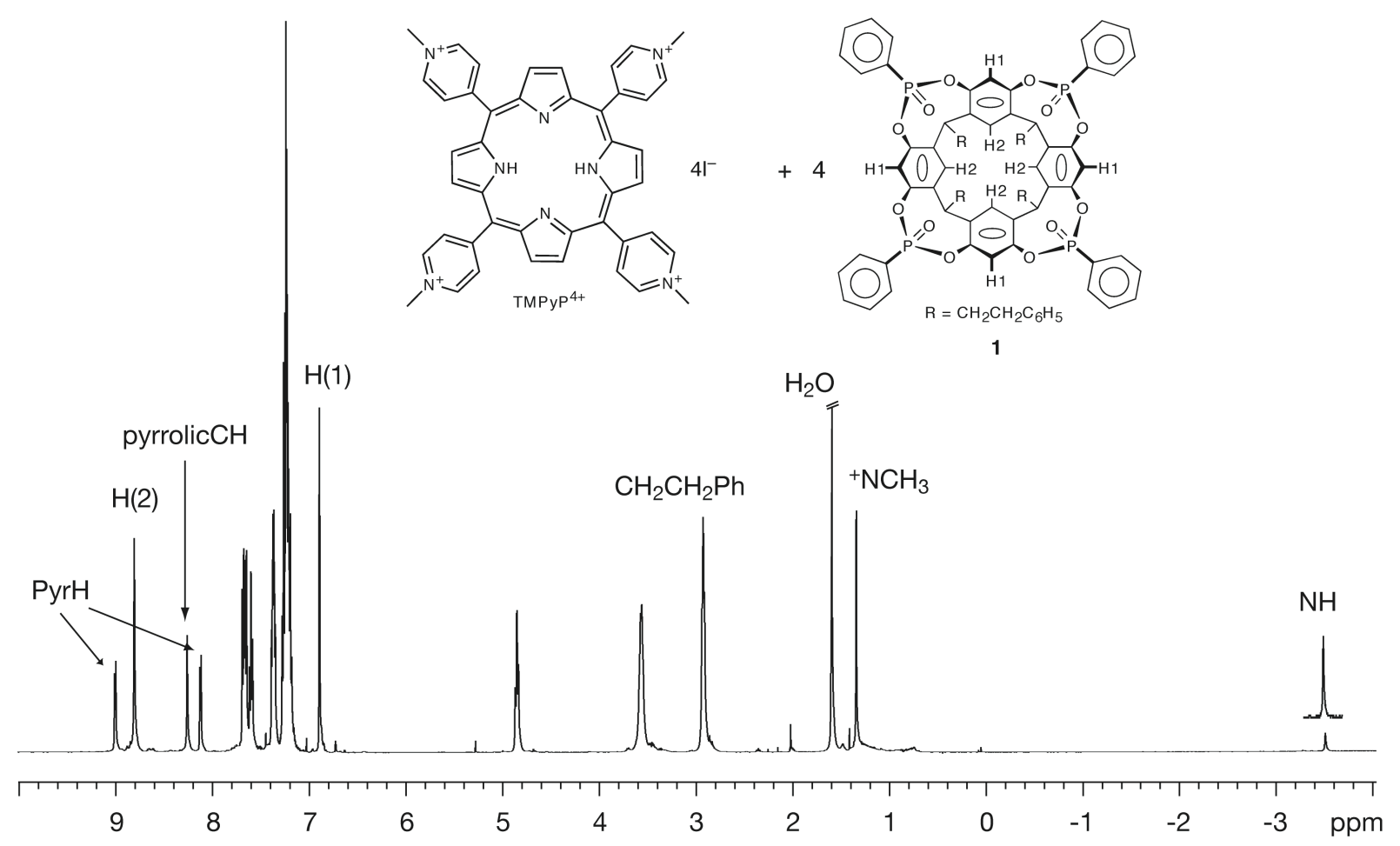

Figure S4. ${ }^{1} \mathrm{H}$ NMR spectrum $\left(500 \mathrm{MHz}, \mathrm{CDCl}_{3}\right)$ of complex $\left[\mathrm{TMPyP}^{4+}\right]\left[4 \mathrm{I}^{-}\right] \cdot \mathbf{1}_{4}$. 
TABLE S1. Anion Effect on the Chemical Shifts $\delta(\mathrm{ppm})$ of $\mathbf{H}(1)$, $\mathrm{H}(2)$ and $\mathrm{CH}_{2} \mathrm{CH}_{2}$ Protons of 1 in Guest@1 Complexes ${ }^{a}$

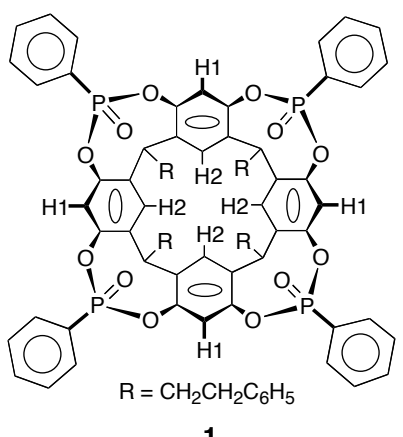

\begin{tabular}{|c|c|c|c|c|}
\hline entry & guest & $\delta[\mathrm{H}(1)]$ & $\delta[\mathrm{H}(2)]$ & $\delta\left[\mathrm{CH}_{2} \mathrm{CH}_{2}\right]$ \\
\hline 1 & none & 6.99 & 7.15 & $2.77 / 2.69$ \\
\hline 2 & {$\left[\mathrm{TMPyP}^{4+}\right]\left[4 \mathrm{I}^{-}\right]$} & 6.89 & 8.81 & $2.92 / 3.56$ \\
\hline 3 & {$\left[\right.$ PicolineNCH $\left.{ }_{3}^{+}\right]\left[\mathrm{Pic}^{-}\right]$} & 6.84 & 7.92 & $2.73 / 2.86$ \\
\hline 4 & {$\left[\right.$ PicolineNCH$\left.{ }_{3}^{+}\right]\left[\mathrm{I}^{-}\right]$} & 6.70 & 8.60 & $2.85 / 3.44$ \\
\hline 5 & {$\left[4,4^{\prime}-\right.$ bipy $\left.\left(\mathrm{NCH}_{3}\right)_{2}{ }^{2+}\right]\left[2 \mathrm{Pic}^{-}\right]^{b}$} & 6.91 & 7.94 & $2.77 / 2.89$ \\
\hline 6 & {$\left[4,4^{\prime}\right.$-bipy $\left.\left(\mathrm{NCH}_{3}\right)_{2}{ }^{2+}\right]\left[2 \mathrm{Cl}^{-}\right]$} & 6.67 & 9.21 & $2.86 / 3.49$ \\
\hline 7 & {$\left[4,4^{\prime}-\right.$ bipy $\left.\left(\mathrm{NCH}_{3}\right)_{2}{ }^{2+}\right]\left[2 \mathrm{PF}_{6}^{-}\right]$} & 6.74 & 8.12 & $2.87 / 3.04$ \\
\hline 8 & {$\left[\mathrm{Et}_{3} \mathrm{NH}^{+}\right]\left[\mathrm{Pic}^{-}\right]$} & 6.81 & 7.86 & $2.74 / 2.85$ \\
\hline 9 & {$\left[\mathrm{Et}_{3} \mathrm{NH}^{+}\right]\left[\mathrm{Cl}^{-}\right]$} & 6.65 & 9.03 & $2.85 / 3.45$ \\
\hline 10 & {$\left[\mathrm{Bu}_{4} \mathrm{~N}^{+}\right]\left[\mathrm{Cl}^{-}\right]$} & 6.66 & 8.62 & $2.84 / 3.30$ \\
\hline
\end{tabular}

